\title{
Paleotempestology and the pursuit of the perfect paleostorm proxy
}

Scott P. Hippensteel, Dept. of Geography and Earth Sciences, University of North Carolina, 9201 University City Blvd., Charlotte, North Carolina 28223, USA, shippens@uncc.edu

Growing populations and recent hurricane activity along the Atlantic and Gulf coastlines have made clear the need for a more accurate and extensive record of storm activity. The paucity of historical descriptions of hurricane strikes along the southern Atlantic coast limits their use as a predictive tool. Only three Category 5 hurricanes have made landfall in the United States since 1900; as a result, the likelihood of a major storm impacting this region cannot be accurately determined using historical records. Proxy records collected from marginal marine environments offer the potential to extend this record back several thousand years, providing better statistical constraints on hurricane prediction and a better understanding of the influence of global warming on catastrophic hurricane development.

Although definitive paleotempest deposits from North America date back to the Oligocene, "paleotempestology" is a relatively new field of research (Boyd and Dyer, 1964). Two proxy approaches developed independently in the early 1990s from two different geographic regions; the resulting storm records offer interesting insights into the problems associated with the contrasting methodologies. At the same time that a research team from Louisiana State University was using sedimentary criteria to detect storm deposits in the coastal lakes of Louisiana, I was finding offshore-indicative foraminifers (and Oligo-Miocene taxa) in buried sand layers from the back-barrier marshes of South Carolina (Liu and Fearn, 1993, 2000; Hippensteel and Martin, 1995, 1999, 2000; Liu, 1999, 2000). Over the next decade, several follow-up studies from the same and different regions led to a series of debates as to the validity of each approach (Donnelly et al., 2000, 2001a, 2001b, 2004; Scott et al., 2003; Donnelly, 2005; Hippensteel et al., 2005; Lambert et al., 2008; Liu et al., 2008).

Previous sediment-based paleotempest proxies have been hindered by two primary issues. First, studies based on sand layers in marshes and coastal lakes have been criticized because the mechanism of deposition was not always well documented, and the source of the sediments was not clearly defined (Otvos, 1999, 2002, 2009; Liu et al., 2009). Second, the depositional history of many marsh records is short, especially in New England and the mid-Atlantic (Donnelly et al., 2000; Travis, 2000). The use of microfossil-enriched storm layers from near
Charleston, South Carolina, avoided both limitations: The mechanism for deposition is well understood because the storm deposits contain offshore-indicative foraminifers, and the record extends into at least the mid-Holocene (Hippensteel and Martin, 1999, 2000).

The micropaleontological proxy is not without problems or critics, however. The exact taxa included on a list of "offshore indicative" genera and the role of bioturbation in the preservation of storm deposits has been strongly debated (e.g., Scott et al., 2003, 2005; Hippensteel et al., 2005; Hippensteel, 2008). Further, the geochronology established for many of these studies is questionable. The washover deposits themselves are, by their very nature, the product of severe reworking of ancient offshore sediments. Dating the foraminifers in such deposits directly would yield the age of the fossils (Oligo-Miocene), not the time of storm deposition.

As a result, the quality, completeness, and comprehensiveness of the storm record from the southeastern Atlantic is not known. Barrier islands are dynamic environments, which, in a transgressive setting, roll over on themselves, destroying or obscuring the backbarrier storm record. Additionally, marsh subenvironments in a transgressive setting will shift through time. In South Carolina, for example, paleostorm frequency appears to be decreasing through time, with more storms lower in the marsh strata (Hippensteel and Harris, 2000; Hippensteel, 2008). Is this apparent decrease in catastrophic storm events a result of climate change or an artifact of the invidious processes of bioturbation and reworking? Is taphonomy partly to blame for the potentially poor preservation, or even absence, of some microfossils in the storm deposits? These marsh subenvironments have, after all, been flooded from high marsh to low marsh, and the primary bioturbators present, fiddler crabs, prefer the low marsh. Before paleotempest proxies reach their potential as a tool for paleoclimate researchers, these geological and biological factors need to be better understood.

The field of paleotempestology has never been of more importance. Prehistorical storm data would be more valuable in the current period of climate change, despite the frustratingly elusive nature of the "ideal" paleostorm record. This ideal paleostorm record, wherever and whenever it is discovered, will have four interrelated characteristics:

1. The deposits will display a clear link to the source of sediments and the mode of deposition. This may be because of the foraminifers present in the deposit, some other 
form of non-cosmopolitan microfossil, or a mineralogical composition that is unique to the offshore or nearshore source material.

2. There must be an extensive record of storms dating to several thousand years. As such, the region of deposition must not be very dynamic, or both the source of sediment and the mode of deposition would be inconsistent through time.

3. The location must have received enough storm activity that the record would be of interest to meteorologists and climatologists seeking a link between sea-surface temperature and the role of the Bermuda High in deflecting storms into either the Gulf of Mexico or the eastern Atlantic coastline.

4. The record must be reproducible in the immediate region and, ideally, reproducible using various proxies. In other words, the deposits must be spatio-laterally continuous in the strata, and two records from the same depositional setting must be identical. This demands minimal physical reworking of the deposits or bioturbation.

I'm currently searching, unfortunately with marginal success, for this record in the marshes of the Outer Banks of North Carolina, and others have recently reported on searches from areas as geographically diverse as Central America (McCloskey and Keller, 2009; Urquahart, 2009) and Massachusetts (Madsen et al., 2009). The potential storm record is worth the effort, especially when the value of a millennial-scale record of hurricanes is considered with respect to growing coastal population and infrastructure.

\section{REFERENCES CITED}

Boyd, D.R., and Dyer, B.F., 1964, Frio barrier bar system of south Texas: Transactions of the Gulf Coast Association of Geological Societies, v. 14, p. 309-322.

Donnelly, J.P., 2005, Evidence of past intense tropical cyclones from backbarrier salt pond sediments: A case study from Isla de Culebrita, Puerto Rico, USA: Journal of Coastal Research, v. 42, p. 201-210.

Donnelly, J.P., Ettinger, R., and Cleary, P., 2000, Sedimentary evidence of prehistoric hurricane strikes in southern New England: Geological Society of America Abstracts with Programs, v. 32, no. 7, abstract A512.

Donnelly, J.P., Roll, S., Wengren, M., Butler, J., Lederer, R., and Webb, T., III, 2001a, Sedimentary evidence of intense hurricane strikes from New Jersey: Geology, v. 29, p. 615-618.

Donnelly, J.P., Bryant, S.S., Butler, J., Dowling, J., Fan, L., Hausmann, N., Newby, P., Shuman, B., Stern, J., Westover, K., and Webb, T., III, 2001b, $700 \mathrm{yr}$ sedimentary record of intense hurricane landfalls in southern New England: Geological Society of America Bulletin, v. 113 , p. 714-727.

Donnelly, J.P., Butler, J., Roll, S., Wengren, M., and Webb, T., 2004, A backbarrier overwash record of intense storms from Brigantine, New Jersey: Marine Geology, v. 210, p. 107-121.

Hippensteel, S.P., 2008, Preservation potential of storm deposits in backbarrier marshes: Journal of Coastal Research, v. 24, p. 594-601.

Hippensteel, S.P., and Harris, M.S., 2000, Frequency of hurricanes along the South Carolina coast: Foraminifera as natural tracers: Geological Society of America Abstracts with Programs, v. 32, no. 7, abstract A513.

Hippensteel, S.P., and Martin, R.E., 1995, Foraminifera as indicators of overwash deposits and barrier island sediment supply, Folly Beach, South Carolina: SEPM Congress on Sedimentary Geology, St. Petersburg, Florida, USA, 13-16 August, Abstracts with Program, p. 69.

Hippensteel, S.P., and Martin, R.E. 1999, Foraminifera as an indicator of overwash deposits, barrier island sediment supply, and barrier island evolution, Folly Island, South Carolina: Palaeogeography, Palaeoclimatology, Palaeoecology, v. 149, p. 115-125.

Hippensteel, S.P., and Martin, R.E. 2000, Foraminifera as indicators of storm deposition: Implications for barrier island sediment supply and evolution, in Martin, R.E., ed., Environmental Micropaleontology: Dordrecht, Kluwer Press, p. 351-369.

Hippensteel, S.P., Martin, R.E., and Harris, M.S., 2005, Discussion: Records of prehistoric hurricanes on the South Carolina Coast based on micropaleontological and sedimentological evidence, with comparison to other Atlantic Coast records: Geological Society of America Bulletin, v. 117, p. 250-256.

Lambert, W.J., Aharon, P., and Rodriguez, A.B., 2008, Catastrophic hurricane history revealed by organic geochemical proxies in coastal lake sediments: A case study of Lake Shelby, Alabama (USA): Journal of Paleolimnology, v. 39, p. 117-131.

Liu, K.-B., 1999, Millennial-scale variability in catastrophic hurricane landfalls along the Gulf of Mexico coast: Dallas, Texas, 23rd Conference on Hurricanes and Tropical Meteorology, January 1999, preprint volume: Boston, Massachusetts, American Meteorological Society, p. 374-377.

Liu, K.-B., 2000, Coastal lakes hold hurricane history: Science News, v. 144, p. 191.

Liu, K.-B., and Fearn, M.L., 1993, Lake-sediment record of late Holocene hurricane activities from coastal Alabama: Geology, v. 21, p. 793-796.

Liu, K.-B., and Fearn, M.L, 2000, Reconstruction of prehistoric landfall frequencies of catastrophic hurricanes in northwestern Florida from lake sediment records: Quaternary Research, v. 54, p. 238-245.

Liu, K.-B., Lu, H., and Shen, C., 2008, A 1,200-year proxy record of hurricanes and fires from the Gulf of Mexico coast: Testing the hypothesis of hurricane-fire interactions, Quaternary Research, v. 69, p. 29-41.

Liu, K.-B., Lu, H., and Shen, C., 2009, Some fundamental misconceptions about paleotempestology: Quaternary Research, v. 71, p. 253-254.

Madsen, A.T., Duller, G.A.T., Donnelly, J.P., Roberts, H.M., and Wintle, A.G., 2009, A chronology of hurricane landfalls at Little Sippewissett Marsh, Massachusetts, USA, using optical dating: Geomorphology, v. 109, p. 36-45.

McCloskey, T.A., and Keller, G., 2009, 5000 year sedimentary record of hurricane strikes on the central coast of Belize: Quaternary International, v. 195, p. 53-68.

Otvos, E.G., 1999, Quaternary coastal history, basin geometry and assumed evidence for hurricane activity, northeastern Gulf of Mexico coastal plain: Journal of Coastal Research, v. 15, p. 438-443.

Otvos, E.G., 2002, Discussion of "Prehistoric landfall frequencies of catastrophic hurricanes..." (Liu and Fearn, 2000): Quaternary Research, v. 57 , p. $425-428$.

Otvos, E.G., 2009, Discussion of "A 1200-year proxy record of hurricanes and fires from the Gulf of Mexico coast..." (Liu et al., 2008): Quaternary Research, v. 71, p. 251-252.

Scott, D.B., Collins, E.S., Gayes, P.T., and Wright, E., 2003, Records of prehistoric hurricanes on the South Carolina coast based on micropaleontological and sedimentological evidence, with comparison to other Atlantic Coast records: Geological Society of America Bulletin, v. 115, p. $1027-1039$.

Scott, D.B., Collins, E.S., Gayes, P.T., and Wright, E., 2005, Records of prehistoric hurricanes on the South Carolina coast based on micropaleontological and sedimentological evidence, with comparison to other Atlantic Coast records: Reply: Geological Society of America Bulletin, v. 117, p. 254-256.

Travis, J., 2000, Hunting prehistoric hurricanes: Storm-tossed sand offers a record of ancient cyclones: Science News, v. 157, p. 333-335.

Urquhart, G.R., 2009, Paleoecological record of hurricane disturbance and forest regeneration in Nicaragua: Quaternary International, v. 195 , p. $88-97$.

Manuscript received 4 Sept. 2009; accepted 25 Jan. 2010. 